\title{
過敏性腸症候群の原因としての 腸管の微細炎症
}

\section{石原俊治三島 義之 古谷聡史 福庭暢彦川島 耕作 木下芳一}

過敏性腸症候群（irritable bowel syndrome：IBS）は, 腹痛等の腹部症状に排便頻度や便性状の変化を伴う機 能性消化管疾患の1つである. IBSの病態は，心理的ストレスと腸管知覚過敏が複雑に絡み合う“脳腸相関”に 依存するところが大きい. しかし，最近では，急性胃腸炎後に発症するpost-infectious IBS（PI-IBS）に関する 臨床的・基礎的研究が進み, PI-IBSの病態には, 腸管粘膜の微細な慢性炎症や免疫異常が関連することが明らか となった. 粘膜の慢性炎症は, さまざまなメカニズムを介して内臓知覚過敏も誘発している. 一方, PI-IBSの病 態の形成と持続には, 粘膜透過性の亢進が深く関わることも報告されている. IBSでは, 機能と炎症のオーバー ラップという新たな病態が注目されているが, 未だ不明な点も多く，今後のさらなる解明が待たれる.

〔日内会誌 109：288～292，2020]

Key words 過敏性腸症候群（IBS），post-infectious IBS，腸管の微細炎症

\section{はじめに}

過敏性腸症候群（irritable bowel syndrome : IBS）は，反復する腹痛や腹部不快感を主な症状 とし, その症状に下痢や便秘等の便通異常を伴 う機能性消化管疾患である.一般に, IBSでは小 腸や大腸に器質的疾患が認められず，その病態 は心理的ストレスと内臓知覚過敏の相互作用 （脳腸相関）に依存するところが大きいと考え られてきた。しかし, 最近では, 一部のIBSにお いて, 腸管粘膜の微細な慢性炎症が病態に深く 関わることが明らかとなってきた。本稿では, 主に急性胃腸炎後に発症するIBS（post-infectious IBS : PI-IBS）の病態に着目し, PI-IBSの腸 管粘膜に存在する微細な炎症の病態と腸管機能
異常との関連について考察する.

\section{IBSの診断と頻度}

IBSの病態について述べる前に, IBSの診断及 び罹患頻度について簡単に触れておきたい. IBS の診断はRome基準によってなされてきたが, 現 在では, Rome IV基準が世界的に広く用いられ ている1)(表 1). IBSでは, 繰り返す腹部症状, 症状と関連する排便頻度 ・便性状の変化が特徵 的であり，優勢症状や便性状によって下㾥型， 便秘型, 混合型ならびに分類不能型に分類され る. Rome基準は “symptom-based criteria”であ ることから，診断に際し，内視鏡検査等による 器質的疾患の除外は必須ではない.しかし, 50 


\section{表1＼cjkstart過敏性腸症候群の診断基準：Rome IV}

(Drossman DA, et al: Rome IV functional gastrointestinal disorders: disorders of gut-brain interaction. Rome Foundation, 2016)

過去3力月，1週間につき1回以上にわたつて腹痛 があり，以下の 2 項目以上を満たし，症状は6力 月以上前から出現していること.

(1)排便によって症状が軽快する.

(2)排便頻度が症状の変化と関連している

(3)便の形状が症状の変化に関連している.

歳以上, 警告症状（体重減少, 発熱, 血便なら びに大腸がんの既往歴や家族歴）を有する場合 には，内視鏡検査によって腫瘍性疾患や炎症性 疾患を除外したうえで診断されるべきである.

IBSの頻度については, Rome II基準を用いた 調査では $1.1 〜 14 \% ，$ 本邦でのRome IIあるいは Rome IIIを用いた報告では3.8～31.0\%となって いる ${ }^{2,3)}$. 大腸内視鏡検査を施行した 4,528 人を 対象に行った我々の検討では, 器質的疾患を除 外したIBSの頻度は $4.2 \%$ であった（Rome III基 準)。このように，過去に報告されているIBSの 頻度は幅が大きく，その要因が調査集団や診断 方法等に依存していることを念頭に置いて, データを評価する必要がある。

\section{IBSの病態における心理的ストレスと 内臓知覚過敏}

心理的ストレスと内臓知覚過敏は，相互に密 接に関連しており（脳腸相関），その悪循環が腸 管運動異常を介してIBSの病態を形成している. さまざまな心理的要因によって中枢神経系が刺 激されると，視床下部からストレス関連ペプチ ドである corticotropin-releasing hormone (CRH, 副腎皮質刺激ホルモン放出因子) が分泌され, 遠心性に腸管クロム親和性細胞（enterochromaffin cells：EC細胞）からのセロトニン （5-hydroxytryptamine：5-HT）を遊離させる。 5-HTは，腸管運動に密接に関わる神経伝達物質

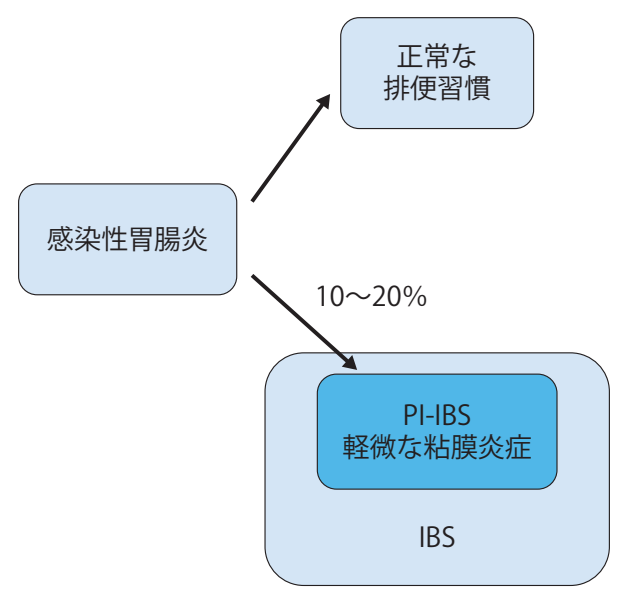

図1 post-infectious IBSの発症と頻度

であり，遊離した 5-HTは，腸管神経叢の 5-HT 受容体を刺激してアセチルコリン遊離を促し, 腸管運動の異常をもたらす。一方，腸管運動異 常による便通異常や腹部症状は, 内臟知覚過敏 と密接に関連し, 求心性経路によって心理的ス トレスをさらに増悪させ，遠心性経路と複雑に 絡み合い，病態の悪循環が形成される。

\section{IBS患者における腸管粘膜の炎症}

\section{1） PI-IBSの臨床的特徵}

IBSの病態における粘膜炎症や免疫異常の関 与について議論されるようになったのは, PI-IBSの概念の確立によるところが大きい. 1996 年, McKendrickは, サルモネラ感染症を 起こした集団を経過観察し，1年後に $31 \%$ の患 者にIBS症状を認めた ${ }^{4)}$. 1999年に発表された Gweeらの報告でも，急性胃腸炎後3カ月で患者 の $23.4 \%$ にIBS症状を認めた ${ }^{5)}$.これらの報告が 引き金となり，以降のPI-IBS関連の報告が多く なされ，急性胃腸炎後には患者の10～20\%程度 がIBSを発症することが明らかとなっている1,2) (図 1).PI-IBSでは，non-PI-IBSに比べて下痢型 が多く, 発症の危険因子としては, 女性, 重症 
な胃腸炎の罹患，うつ傾向や心理的不安ならび に細菌毒素等が挙げられている11.

\section{2）IBSに認められる軽微な粘膜炎症}

一部のIBS患者では, 腸管粘膜の軽微な炎症や 局所あるいは全身の免疫異常が認められること が報告されており，その傾向はPI-IBSで顕著で ある ${ }^{6)}$ 末梢血の表面マーカーの解析では, 活 性化 T細胞 $\left(\mathrm{CD}^{\circ} 9^{+}\right)$, 腸管志向性の強いインテ グリン $\beta 7$ を発現するT細胞やB細胞のポピュ ラーションの増加がIBSで認められる。 また, PI-IBSの患者の腸管粘膜では，IL（interleukin）$1 \beta$, IL-8, TNF (tumor necrosis factor)- $\alpha$, IFN (interferon) $-\gamma$ 等の炎症性サイトカインの発現は 高いが, IL-10等の制御性サイトカインの発現は 低下していること，粘膜固有層内には肥満細 胞，マクロファージならびにCD3 ${ }^{+} \mathrm{T}$ 細胞の浸潤 が目立つこと，EC細胞の過形成と共に粘膜内の セロトニンや神経ペプチドの含有量が増加して いることも報告されている。ささに，PI-IBSあ るいは下痢型IBS患者に特徵的な点として, 自然 免疫応答の活性化が報告されている。これらの 患者では, 腸管粘膜局所において, 種々のTolllike receptor（TLR）の発現とそのシグナルが立 進していること，末梢血単核球がLPS (lipopolysaccharide）刺激に反応して過剩な炎症性サイ トカイン産生を示すこと, グラム陰性桿菌の鞭 毛成分であるflagellinに対する抗体が血清中に 認められること，便中では $\alpha$-defensinや $\beta$-defensinの含有量が増加していることが報告 されている(表2)。これらの結果は, PI-IBSの 患者では微生物に対する感受性京進が認められ ることを示唆するものであり, 病態と腸内細菌 との関連を考えるうえでも興味深い.

\section{PI-IBSの病態に関連する 腸管粘膜透過性の亢進}

前述したように, PI-PBSの病態には, 感染後

\section{表2 IBS患者における自然免疫応答（文献6を改变）}

\begin{tabular}{cr}
$\begin{array}{l}\Delta \text { TLRの発現（生検組織） } \\
\text { 上昇 }\end{array}$ & \\
& TLR4，5 \\
低下 & TLR2，4 \\
\hline & TLR7，8
\end{tabular}

TLRリガンド刺激時のサイトカイン産生 (末梢血血球)

上昇 TLR2 (Pam3Cys) TNF- $a$

TLR3 (PolyI: C) IL-8

TLR4（LPS） IL-1 $\beta$, IL-6\#, IL-8, TNF- $a$

TLR5 (Flagellin) IL- $1 \beta$, TNF- $\alpha$

TLR7 (Limiquimod) IL-8

低下 TLR4（LPS） IL-10，IL-12，TNF- $a$

遺伝子多型 TLR9

血清抗体

anti-flagellin抗体

便中抗菌ペプチド

$\beta$-defensin-2の増加

に誘発される腸管粘膜の持続的慢性炎症が深く 関わっている。それでは，なぜこのような慢性 炎症の持続が誘発されるのであろうか。本メカ ニズムに関するこれまでの研究は非常に少ない が，急性胃腸炎によって不可逆的な粘膜透過性 巟進が惹起され，腸内細菌や種々の抗原に対す る免疫応答が持続的に誘発された状態が推測さ れる. Handらは，マウスモデルを用い，急性胃 腸炎後には体内に腸内細菌が侵入し，特異的 T 細胞が増加すること，その特異的T細胞は長期 間生存し，以降の刺激によって即座に活性化す ることを報告している7)。 また，ヒトにおいて も本メカニズムと関連する興味深い報告がなさ れている. Villaniらは, カナダのWalkertonにお ける大規模な食中毒発生後にPI-IBSを発症した 患者のサンプルを用いてPI-IBS発症に関わる遺 伝子解析を行い, IL-6, TLR9 と共にCDH1（E-力 ドヘリン）遺伝子のSNPs（single nucleotide polymorphisms）がPI-IBSの発症リスク因子にな ることを報告した ${ }^{8)}$. E-カドヘリンはタイトジャ ンクション蛋白の1つであり，その発現や機能 の変化は粘膜透過性の亢進に影響を与える可能 性がある。さらに，炎症によって誘導される myosin light chain kinase (MLCK) は, 収縮 cytoskeleton収縮とタイトジャンクション機能 


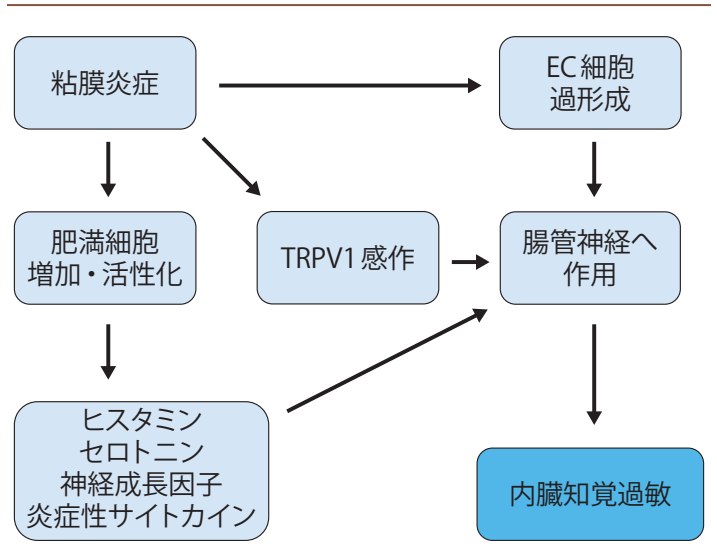

図2 腸管の炎症と内臓知覚過敏との関連

の低下を誘発して粘膜透過性を六進させるが, このメカニズムがIBSの病態に関わる可能性が 示唆されている ${ }^{9)}$.

\section{5. 粘膜炎症と内臓知覚過敏}

IBS（特にPI-IBS）の腸管粘膜では，さまざま な免疫担当細胞が浸潤していることは前述した が, なかでも, 肥満細胞の増加・活性化とEC細 胞の過形成は特徵的であり, IBSの病態に深く関 わっている。肥満細胞からは, セロトニン, ヒ スタミン, 神経成長因子ならびに炎症性サイト カイン等が放出され，これらの因子が腸管知覚 神経を刺激する ${ }^{1,6)}$. さらに, 炎症粘膜では, カ プサイシン受容体 (transient receptor potential cation channel, subfamily V, member 1 : TRPV1) が感作され, 遊離されるサブスタンスPやcalcitonin gene-related peptide（CGRP）と共に知覚 過敏を誘発する ${ }^{10)}$. また, 粘膜炎症は, セロト ニンの取り込みを調節している serotonin transporter（SERT）の発現を低下させることが明ら かとなっており, SERTの発現低下は, 局所での セロトニン作用が高まり, 下痢型IBSの病態に関 わっていると考えられる(図2).

\section{6. 臨床的寛解期の炎症性腸疾患における IBS様症状}

Crohn病 (Crohn's disease : CD) や潰瘍性大腸 炎（ulcerative colitis：UC）等の炎症性腸疾患 （inflammatory bowel disease：IBD）は, 免疫異 常を伴う器質的疾患であり, 機能性消化管疾患 であるIBSとは異なる病態と考えられる。しか し，臨床的寛解に至ったIBD患者の一部におい て“IBS様症状”が認められることは広く認識さ れている. 最近のメタ解析では, 臨床的寛解UC 患者におけるIBS様症状の頻度は $31 \%$ であると 報告された ${ }^{11)}$ 。寛解期UC患者におけるIBS様症 状と残存する粘膜炎症との関連を検討する目的 で, 大腸内視鏡検査, 便中カルプロテクチン測 定ならびに生検による組織学的炎症の評価が行 われた報告が少数ながら散見される ${ }^{12)}$. しか し, 残存する軽微な炎症がIBS様症状と相関した とする報告と，関連が認められなかったとする 報告が混在しており，臨床的寛解IBD患者にお けるIBS様症状に残存するUCの微細な粘膜炎症 が関連するかどうかについては，今後のさらな る検討が必要と思われる.

\section{おわりに}

IBSの病態について, 特に急性胃腸炎後に発症 するPI-IBSの病態に焦点を当てて解説した. PI-IBSでは, 明らかに粘膜局所の炎症や自然免 疫の活性化が誘発されており，その不可逆的な 慢性炎症には, 粘膜透過性亢進が密接に関わっ ていると考えられる.また, IBSで認められる軽 微な慢性炎症は，さまざまなメカニズムを介し て腸管神経を刺激し, 内臓知覚過敏を誘導して いる. IBSの病態は, 遺伝子的要因, 環境因子を 背景とした脳腸相関に依存するところが大きい が，そこに軽微な腸管炎症と免疫異常という新 たな因子が加わってきた。近年では, IBSとIBD の病態の関連も注目されており, 機能と炎症の 
オーバーラップという観点から，両疾患の病態

解析が進んでいくことを期待したい.
著者のCOI (conflicts of interest) 開示：石原俊治；研究 費・助成金（EAファーマ，ヤンセンファーマ)，寄附金 (アステラス製薬，武田薬品工業)，木下芳一; 講演料 (アステラス製薬，アストラゼネカ，EAファーマ，大塚 製薬，第一三共，武田薬品工業，マイランEPD)，寄附金 (アステラス製薬，EAファーマ，ゼリア新薬工業）

1) Lacy BE, et al : Bowel disorders. Gastroenterology $150: 1393-1407,2016$.

2) Spiller R, et al : Guidelines on the irritable bowel syndrome : mechanisms and practical management. Gut 56 : 1770-1798, 2007.

3) Ishihara $\mathrm{S}$, et al : Irritable bowel syndrome and inflammatory bowel disease : infectious gastroenteritis-related disorders? Clin J Gastroenterol 2 : 9-16, 2009.

4) McKendrick MW : Post Salmonella irritable bowel syndrome—c review. J Infect 32 : 170-171, 1996.

5) Gwee KA, et al : The role of psychological and biological factors in postinfective gut dysfunction. Gut 44 : 400406, 1999

6) Ishihara $\mathrm{S}$, et al : Pathogenesis of irritable bowel syndrome--review regarding associated infection and immune activation. Digestion 87 : 204-211, 2013.

7) Hand TW, et al : Acute gastrointestinal infection induces long-lived microbiota-specific T cell responses. Science 337 : 1553-1556, 2012.

8) Villani AC, et al : Genetic risk factors for post-infectious irritable bowel syndrome following a waterborne outbreak of gastroenteritis. Gastroenterology $138: 1502-1513,2010$.

9) Odenwald MA, Turner JR : Intestinal permeability defects : is it time to treat? Clin Gastroenterol Hepatol 11 : 1075-1083, 2013.

10) Balemans D, et al : Evidence for long-term sensitization of the bowel in patients with post-infectious-IBS. Sci Rep $7: 13606,2017$.

11) Halpin SJ, Ford AC : Prevalence of symptoms meeting criteria for irritable bowel syndrome in inflammatory bowel disease : systematic review and meta-analysis. Am J Gastroenterol 107 : 1474-1482, 2012.

12) Ishihara $S$, et al : Irritable bowel syndrome-like symptoms in ulcerative colitis patients in clinical remission: association with residual colonic inflammation. Digestion $99: 46-51,2019$. 